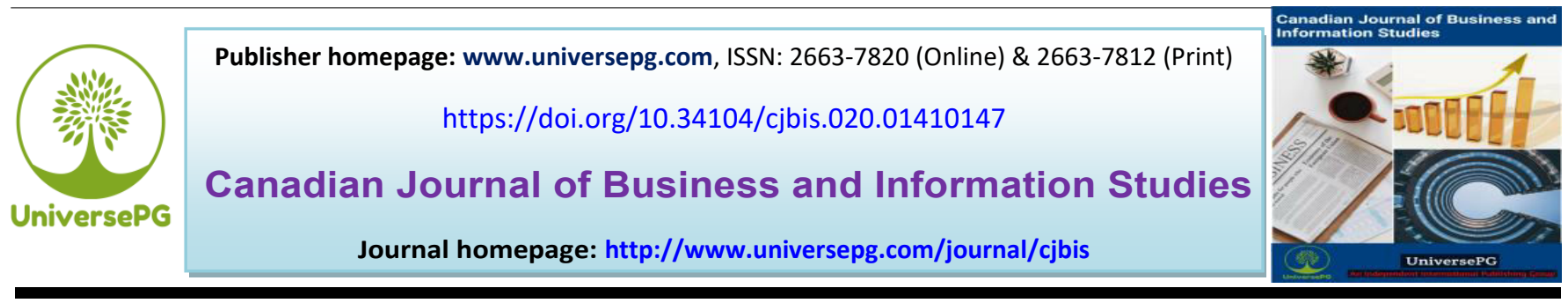

\title{
Determinants of Customer Loyalty towards Bank: A Probit Regression Based Approach
}

\author{
Mohammad Ahsan Uddin* \\ Department of Statistics, University of Dhaka, Dhaka, Bangladesh. \\ *Correspondence: munna_stat@yahoo.com (Mohammad Ahsan Uddin, Associate Professor, Department of Statistics, \\ University of Dhaka, Bangladesh).
}

\begin{abstract}
In present days banks realize the importance of customer loyalty and its potential to help them acquire new customers and retain existing ones and maximize their lifetime value. This study employed the binary probit model to investigate the determinants of customer loyalty to the banking sector of Bangladesh by interviewing 1000 randomly selected bank customers. It reveals that the levels of loyalty were high among customers of private commercial and development banks relative to customers of government banks. Although customer loyalty was observed as a key determinant of a customer's satisfaction with a bank, these were indeed related to the levels of services provided to the customer. Good ATM services promote customer's convenience and flexibility thereby ensuring loyalty. For reducing the difficulties in choosing a proper banking scheme proper guidance from bank staff is another determinant of customer loyalty. Adequacy of other banking facilities like mobile banking and availability of help counter in bank causes a customer to be loyal to a bank. Also, in order to increase loyal customers, banks should consider establishing branches at convenient locations to bring banking to the doorstep of their customers. Overcrowding in the banks and increasing the time taken to transact for this reason customers have to wait too long loyalty may decrease. Thus sufficient seating arrangement in banks has influence in increasing customer's loyalty. In order to increase the customer's loyalty bank must take all complains and problems seriously and solve them using advanced technology.
\end{abstract}

Keywords: Customer Relationship Management (CRM), Loyalty, Binary, Probit regression, and Goodness of fit.

\section{INTRODUCTION:}

In today's business arena, customers are prime asset, hence managing the customer relation is equally critical for the organizations (UlHaq et al., 2010; Jalil and Karami, 2020). Today's financial institutions are undergoing tremens-dous revolutions in its scope of work due mainly to competition and products diversification among the actors in the industry (Oduro-Senyah et al., 2009). Due to competitive business environment, to get competitive advantage good relationship with customers is of significant UniversePG lwww.universepg.com importance (Recklies, 2006). Indeed, 5\% more investment on customer loyalty may produce $100 \%$ more profit (Reichheld and Sasser, 1990). Competitive bank industry requires customer centric personalized and differentiating services to boost up business (Khaled and Abdul Rasoul, 2008).

Loyalty is positively correlated with trust, when the trust of customers on bank increases; it will be reflected in increased loyalty of customers (Lauren and Lin, 2003; Zikmund, 2001; Lin and Wang, 2006). 
Service quality and customer satisfaction have an effect on customer loyalty (Laroche and Taylor, 1988; Fornell, 1992; Hallowell, 1996; Oliver, 1997; Chumpitaz et al., 2004; Kotler and Armstrong, 2006; Afsar et al., 2010).To retain customers, customer relationship management and delivering superior customer value is essential (Chen \& Hitt, 2002; Wang et al., 2004). To retain customers and get economic incentives affective commitments, loyalty programs, monitoring and evaluating relationship quality over time and communication are important tools (Gray \& Byun, 2001; Verhoef, 2003a; Zeithaml \& Bitner, 2003).

\section{MATERIALS AND METHODS:}

Data Source and Sample Size - The study is based on both primary and secondary data. The target population of our study is all the bank customers of all banks of Bangladesh. For the study primary data of 1000 randomly selected bank customers were collected. Also secondary data were collected from bank websites, annual reports of bank, newspapers and magazines. For the above study the following formula was used for determining required sample size:

$$
n=\frac{z^{2}{ }_{1-\frac{\alpha}{2}}}{d^{2}} p q
$$

Where,

$\mathrm{n}=$ Sample size

$\mathrm{z}=$ Standard normal deviate $=1.96$

$\mathrm{p}=$ Assumed proportion in the target population $=0.38$ (assumed)

$\mathrm{d}=$ degree of accuracy desired in the estimated proportion $=0.03$

$q=1-p=1-0.38=0.62$

So, $n=\frac{z^{2} 1-\frac{\alpha}{2}}{d^{2}} p q=\frac{(1.96)^{2}(0.62)(0.38)}{0.03^{2}}=1005 \approx 1000$

Probit Model to investigate customer's loyalty toward bank - Customers' loyalties to a bank are expressed in two categories: "loyal" and "not loyal". Thus our investigation employ a binary choice model, regression with binary dependent variable makes a sense of non-linearity, which can be analyzed through the probit and log it models (Maddala, 1992; Greene,
2003; Hill et al, 2008; Gujarati and Porter, 2009). We want to know the variables which are responsible for customer's loyalty and their marginal effects on customer's loyalty by using probit regression model. That is, the probit model expresses the probability $P_{i}$ that observed $L_{i}$ from Binomial processtakes the value 1. Hence to estimate the probabilities of customer loyalty to a bank, the authors specify the model:

$$
L_{i}^{*}=X_{i}^{\prime} \beta+\varepsilon_{i}
$$

Where $L_{i}^{*}$ is loyalty and a latent variable which can be related to the observable binary variable $L_{i}$ :

$$
L_{i}= \begin{cases}1, & L_{i}^{*}>0 \\ 0, & \text { otherwise }\end{cases}
$$

The coefficients $\beta$ is the vector of Unknown parameter estimates and the $\varepsilon_{i}$ is the stochastic error term assumed to be normally distributed. The interpretation of coefficients $\beta$ 's is complex; hence the model is best interpreted by computing the marginal effects (Greene 2003; Hill et al., 2008; Stock and Watson, 2016). The $X_{i}$ is a vector of explanatory factors and consists of bank's dimension, technological services, distance to bank from customers Residence, customer gender, availability of mobile banking, availability of ATM facility, adequacy of other banking facilities, Switch cost, and transaction time condition, etc.

\section{RESULTS AND DISCUSSION:}

At first we focus on model diagnostic. For this model, Hosmer and Lemeshow, (2000) goodness of fit (GOF) test is performed which results a p-value $=0.2098$ which is greater than .05 . As sample size is large enough, the resulting p-value implies that fewer than $5 \%$ level of significance we have enough evidence to conclude that the model is correctly specified.

The Table 1 also contains pseudo $\mathrm{R}^{2}$ of 0.4595915 and Wald chi square test statistic with value 244.2. This Wald chi-square has a p-value of 0.000 indicating the pseudo R-squared and the Wald chi-square are statistically significant at the 5\% level of significance. It indicates that all the explanatory variables included in the model together explain the loyalty of customers to their most frequently used banks. 
Table 2: Probit regression result for marginal effect on loyalty

\begin{tabular}{|c|c|c|c|c|}
\hline Variables & Marginal effect $=\frac{d F}{d x}$ & Std. Err. & $\bar{Z}$ & $\overline{\mathbf{P}>|\mathbf{z}|}$ \\
\hline Customized Services & 0.158564 & 0.045543 & 3.4816 & $0.0004984 * * *$ \\
\hline Transaction Time & 0.211641 & 0.050219 & 4.2143 & $2.505 \mathrm{e}-05 * * *$ \\
\hline Sufficient No. of ATM & 0.179160 & 0.055922 & 3.2037 & $0.0013567 * *$ \\
\hline Benefitted offers & 0.206443 & 0.041913 & 4.9255 & $8.414 \mathrm{e}-07 * * *$ \\
\hline Proper Guidance of Staff & 0.332626 & 0.043252 & 7.6904 & $1.467 \mathrm{e}-14 * * *$ \\
\hline Availability of help counter in branch & 0.178540 & 0.042240 & 4.2268 & $2.370 \mathrm{e}-05 * * *$ \\
\hline Problem solved over phone call & 0.138928 & 0.044856 & 3.0972 & $0.0019535 * *$ \\
\hline Availability of Mobile banking & 0.358642 & 0.043507 & 8.2434 & $<2.2 \mathrm{e}-16 * * *$ \\
\hline Use of advance technology & 0.338604 & 0.041381 & 8.1826 & $2.779 \mathrm{e}-16 * * *$ \\
\hline Branch convenient location & 0.297621 & 0.046288 & 6.4297 & $1.278 \mathrm{e}-10 * * *$ \\
\hline 24x7 Service from ATM & 0.177580 & 0.044041 & 4.0322 & $5.526 \mathrm{e}-05 * * *$ \\
\hline Competitive Interest rate & 0.312042 & 0.041683 & 7.4860 & $7.100 \mathrm{e}-14 * * *$ \\
\hline \multicolumn{5}{|c|}{$\begin{array}{l}\text { Signif. Codes: } 0 \text { ‘**’’ } 0.001 \text { ‘**’ } 0.01 \text { ‘*’ } 0.05 \text { ‘’ } 0.1 \text { ‘’ } 1 \\
\text { dF/dx is for discrete change for the following variables: } \\
\text { "Q1.10" "Q1.13" "Q1.21" "Q2.06" "Q2.07" "Q2.09" "Q3.07" "Q3.14" "Q3.15" "Q4.04" "Q4.15" "Q5.12" } \\
\text { **Using R studio }\end{array}$} \\
\hline
\end{tabular}

The variable "Sufficient No. of ATM" is significant under 5\% level of significance $(\mathrm{p}$-value $=0.002835$ $<.05)$. The marginal effect value 0.179160 implies that the increase of the number of ATM booths increases customer's loyalty $17.916 \%$ when other covariates are kept at a fixed level. The variable "Benefitted offers" is significant under $5 \%$ level of significance ( $\mathrm{p}$-value = $4.19 \mathrm{e}-06<.05)$. Its corresponding marginal value is 0.206443 and it means that the customers who are benefitted by offers that banks provide them are $20.6443 \%$ loyal towards their most frequently used bank than customers who are not when all other variables are kept at a fixed level. The variable "Proper Guidance of Staff" is significant under 5\% level of significance $(\mathrm{p}$-value $=5.53 \mathrm{e}-12<.05)$. The marginal effect value 0.332626 implies that if bank's staff gives proper guidance about choosing bank schemes then customer's loyalty increases by $33.2626 \%$ when other covariates are kept at a fixed level. The variable "Availability of help counter" is also significant under $5 \%$ level of significance because from table we can see that its corresponding $\mathrm{p}$-value is $1.54 \mathrm{e}-05$ which is less than .05. The marginal effect value 0.178540 implies that if help counter is available in the banks then customer's loyalty increases by $17.8540 \%$ when other covariates are kept at a fixed level.

The variable "Problem solved over phone call" is significant under 5\% level of significance as its corresponding $\mathrm{p}$-value $=.0 .000760<0.05$. The value of its corresponding marginal effect is 0.138928 which indicates that customer's loyalty increases $56.3896 \%$ towards their bank if they feel that the service time of their transaction is alright when other covariates are kept at a fixed level. The variable "Availability of Mobile banking" is significant under 5\% level of significance $(p$-value $=7.99 \mathrm{e}-12<.05)$ and shows a positive impact on customer's loyalty towards bank. The availability of mobile banking facility has an effect of increasing the probability of a customer being loyal to the bank by 0.358642 when all other covariates are kept at a fixed level. The variable "Use of advance technology" is significant under 5\% level of significance $(\mathrm{p}$-value $=1.70 \mathrm{e}-12<.05)$. Its corresponding marginal value is 0.338604 and it means that the customers whose most frequently use banks use advance technology in banking system are $33.8604 \%$ loyal towards their bank than customers who are not provided the facility by their bank when all other variables are kept at a fixed level.

The variable "Branch convenient location" is significant under $5 \%$ level of significance as its corresponding $\mathrm{p}$-value $=9.54 \mathrm{e}-09<0.05$. The value of its corresponding marginal effect is 0.297621 which indicates that customer's loyalty increases $29.7621 \%$ towards their bank when the bank branches are at a convenient location keeping other covariates at a fixed level. The variable " $24 \times 7$ Service from ATM" is also significant under $5 \%$ level of significance because 
from table we can see that its corresponding p-value is $5.25 \mathrm{e}-05$ which is less than .05 . It shows a positive relation with customer's loyalty. The value of its corresponding marginal effect is 0.177580 which indicates that customer's loyalty increases $17.7580 \%$ towards their bank if they get $24 \times 7$ service from ATM booths when other covariates are kept at a fixed level.

The variable "Competitive Interest rate" is significant under $5 \%$ level of significance $(\mathrm{p}$-value $=5.10 \mathrm{e}-13$ <.05) and shows a positive impact on customer's loyalty towards bank. The marginal effect of the variable is 0.312042 which indicated that the competitive interest rate offered by customers' most frequently used bank compared to other banks on loans has an effect of increasing the probability of a customer being loyal to the bank by 0.312042 when all other covariates are kept at a fixed level.

\section{CONCLUSION:}

This study employed the binary probit model to examine the determinants of customers' loyalty to banking sector of Bangladesh. The study found that the levels of loyalty were high among customers of private commercial and development banks relative to customers of government banks. Although, customer loyalty was observed as a key determinant of a customer's satisfaction to a bank, these were indeed related to the levels of services provided to the customer. Good ATM services promote customers convenience and flexibility thereby ensuring loyalty. However, this is plagued with challenges including inadequate ATM points for services which consequently lead to overcrowding in the banks and increasing the time taken to transact. The difficulties in choosing proper banking scheme thus proper guidance from bank staff it the determinant of customer loyalty. Adequacy of other banking facilities like mobile banking and availability of help counter in bank causes a customer to be loyal to a bank. Also, in order to reduce the defection rate of satisfied customers and increase loyal customers, banks should consider establishing branches at convenient location as to bring banking to the doorstep of their customers. This will reduce the risk, cost and inconvenience of having to travel from far places to access their money. Overcrowding in the banks and increasing the time taken to transact for this reason customers have to wait too long loyalty may decrease. Thus sufficient seating arrangement in bank has influence in increasing customer's loyalty. In order to increase customer's loyalty bank must take customer all complains and problem seriously and solve it using advance technology. Customers should be provided such by which they will be surely benefited. Banks should employ efficient and effective marketing strategies not only to be more customers oriented but also to adopt appropriate pricing policies to satisfy their customers because satisfaction has been identified to be linked to pricing.

\section{ACKNOWLEDGMENT:}

First and foremost, the author is grateful to Almighty Allah. The author is also thankful to anonymous reviewers and editors for their helpful comments and suggestions.

\section{CONFLICTS OF INTEREST:}

The author declares no conflict of interest.

\section{REFERENCES:}

1. Afsar, B., Ur Rehman, Z., Qureshi, J. A. and Shahjehan, A. (2010). 'Determinants of customer loyalty in the banking sector: the case of Pakistan'. African Journal of Business Management, 4: 1040-1047.

http://www.academicjournals.org/AJBM

2. Beckett-Camarata, E. J., Camarata, M. R., and Barker, R. T. (1998). Integrating Internal and External Customer Relationships through Relationship Management: A Strategic Response to a Changing Global Environment. $J$. of Business Research, 41(1), 71-81.

https://doi.org/10.1016/S0148-2963(97)00013-1

3. Chen, P., \&Hitt, L. (2002). Measuring Switching Costs and the Determinants of Customer Retention in Internet-Enabled Businesses: A Study of the Online Brokerage Industry. Information Systems Research,, 13(3), 255274. https://doi.org/10.1287/isre.13.3.255.78

4. Chumpitaz, R. and Paparoidamis, N. G. (2004) 'Service Quality and Marketing Performance in Business-to-Business Markets: Exploring the Mediating Role of Client Satisfaction', 
Managing Service Quality, 14: 235-248. https://doi.org/10.1108/09604520410528653

5. Fornell, C. (1992). 'A national customer satisfaction barometer: the Swedish experience', Journal of Marketing, 56: 6-21. https://doi.org/10.1177/002224299205600103

6. Gray, P. and Byun, J. (2001). Customer Relationship Managment: Practical tips for Successful Implementation. https://escholarship.org/uc/item/76n7d23r

7. Greene, W. H. (2003). Econometric Analysis $\left(5^{\text {th }}\right.$ Ed.), New Jersey, Pearson Education, Inc. https://spu.fem.uniag.sk/cvicenia/ksov/obtulovic/ Mana\%C5\%BE.\%20\%C5\%A1 tatistika\%20a\%2 0ekonometria/EconometricsGREENE.pdf

8. Gujarati D. N. and Porter D.C. (2009). Basic Econometrics $\left(5^{\text {th }} \mathrm{ed}\right.$.), Singapore: the McGraw Hill/Irwin Companies.

http://dln.jaipuria.ac.in:8080/jspui/bitstream/123 456789/2623/1/Basic\%20Econometrics\%20-

Gujarati.pdf

9. Gustafsson, A., Johnson, M. D., and Roos, I. (2005). The Effects of Customer Satisfaction, Relationship Commitment Dimensions, and Triggers on Customer Retention. TheJournal of Marketing, 69(4), 210-218.

https://doi.org/10.1509\%2Fjmkg.2005.69.4.210

10. Hallowell, R. (1996). 'The relationships of customer satisfaction, customer loyalty, and profitability: an empirical study'. International Journal of Service Industry Management, 7: 27-42.

https://doi.org/10.1108/09564239610129931

11. Hill, R. C., Griffiths, W. E. and Lim, G. C. (2008). Principles of Econometrics, John Wiley and Sons Inc, New York, USA. https://www.academia.edu/30183056/Hill_Griffi ths_Lim_Principles_of_Econometrics

12. Hosmer D.W. and Lemeshow, S. (2000). Applied Logistic Regression, Second edition, 2000, John, Wiley and Sons, New York, USA. https://doi.org/10.1002/0471722146

13. Jalil MA. and Karami MJH. (2020). A critical exploration of some fundamental terms and terminologies in statistics, Int. J. Mat. Math. Sci., 2(3), 45-50. https://doi.org/10.34104/ijmms.020.045050
14. Khaled A. and Abdul Rasoul H. B, (2008). 'Bank's Customer Satisfaction in Kuwait an Exploratory Study'. Malaysia, Open University. https://www.scribd.com/document/129712986/b anks-customer-satisfaction-in-kuwait-pdf

15. Kotler, P. and Armstrong, G. (2006). Principles of Marketing (11 ${ }^{\text {th }}$ Ed.). Japan, Pearson Education, Inc.

https://www.worldcat.org/title/principles-ofmarketing/oclc/57283926

16. Laroche, M. and Taylor, T. (1988). 'An Empirical Study of Major Segmentation Issues in Retail Banking'. International Journal of Bank Marketing, 6: 31-48.

17. Lauren, P. and Lin. H. H. (2003).'A Customer Loyalty Model for E-Service Context', Journal of Electronic Commerce Res, 4- 4. http://web.csulb.edu/journals/jecr/issues/20034/P aper3.pdf

18. Lin, H. H. and Wang, Y. S. (2006) 'An Examination of the determinants of customer loyalty in mobile commerce context', Information and Management, 43: 271-282. https://doi.org/10.1016/j.im.2005.08.001

19. Maddala, G. (1992). Introduction to Econometrics, $\left(2^{\text {nd }}\right.$ ed.). New York, Macmillan, (Chapter 11).

https://jigjids.files.wordpress.com/2011/05/intro duction-to-econometric-2nd.pdf

20. Oduro-Senyah, A., and Ebo, E. (2009). Customer relationship management in financial institutions in Ghana: a case of standard chartered bank \& state insurance company. Retrieved January 31, 2011. http://epubl.ltu.se/1653-0187/2009/039/

21. Oliver, R. (1997). Satisfaction a Behavioural Perspective on the Customer. McGraw-Hill, New York. https://doi.org/10.4324/9781315700892

22. Recklies, D. (2006). Understanding and Managing Customer Perception. Effective Executive. ICFAI University Press. https://documents.pub/document/understandingand-managing-customer-perception.html

23. Reichheld, F. and Sasser, W. (1990). 'Zero Defections: Quality Comes to Services', HBR. 
24. Stauss, B. (2002). The Dimensions of Complaint Satisfaction: Process and Outcome Complaint Satisfaction Versus Cold Fact and Warm Act Complaint Satisfaction. Managing Service Quality, 12(3), 173-183.

https://doi.org/10.1108/09604520210429240

25. Stock, J. H. and Watson, M. W. (2016). Introduction to Econometrics ( $3^{\text {rd }}$ ed.), New York, Pearson Education, Inc.

https://econometricsweb.files.wordpress.com/20 16/11/stock-watson-econometrics-3rd-editionilovepdf-compressed.pdf

26. UlHaq, I., Ramay, M. I., U Rehman, M., and Jam, F. (2010). Big Five Personality and Perceived CustomerRelationship Management. Research J. of InternationalStudies, (15). https://www.semanticscholar.org/paper/Big-Five-Personality-and-Perceived-Customer-Haq-Ramay/729d75b116e8da73d0f82260cb9b445abfbb $\underline{1023}$

27. Verhoef, P. C. (2003a). Understanding the Effect of Customer Relationship Management
Efforts on Customer Retention and Customer Share Development. Journal ofMarketing, 67(4), 30-45. https://doi.org/10.1509/jmkg.67.4.30.18685

28. Wang, Y., Lo, H. P., Chi, R., and Yang, Y. (2004). An Integrated Framework For Customer Value And Customer-RelationshipManagement Performance: A Customer-Based Perspective From China. Managing Service Quality, 14(2/3), 169-182. https://doi.org/10.1108/09604520410528590

29. Zeithaml, V., andBitner, M. (2003). Service Marketing Integrating Customer Focus Across the Firm ( $3^{\text {rd }}$ ed.). McGraw-Hill, New York. https://pdf.wecabrio.com/services-marketingzeithaml-bitner.pdf

30. Zikmund, W. G. and M. D'Amico, (2001), Marketing Creating and Keeping Customers in an E-commerce World, Cincinnati, $\mathrm{OH}$ : South-Western. https://www.amazon.com/Marketing-CreatingKeeping-Customers-Commerce/dp/0324072694

Citation: Uddin MA. (2020). Determinants of customer loyalty towards bank: a probit regression based approach, Can. J. Bus. Inf. Stud., 2(6), 141-147. https://doi.org/10.34104/cjbis.020.01410147 () 